特集 海綿静脈洞部内頚動脈瘤

\title{
海綿静脈洞部内頝動脈瘤に対する治療戦略
}

\author{
村岡賢一郎, 冨田 陽介, 桑原研, 高橋悠, 大熊佑 \\ 田邊 智之, 寺田 欣矢, 目黒 俊成, 廣常 信之, 西野 繁樹
}

\section{Treatment Strategy for Cavernous Carotid Aneurysm}

\author{
Kenichiro Muraoka, M.D., Yousuke Tomita, M.D., Ken Kuwahara, M.D., Yu TaKahashi, M.D., \\ Yu Okuma, M.D., Tomoyuki Tanabe, M.D., Kinya Terada, M.D., Toshinari Meguro, M.D., \\ Nobuyuki Hirotsune, M.D., and Shigeki Nishino, M.D. \\ Department of Neurosurgery, Hiroshima City Hospital, Hiroshima, Japan
}

\footnotetext{
Key words:

- cavernous carotid aneurysm

- parent artery occlusion

- endosaccular coil embolization

- mass effect

- stent assist technique
}

Surg Cereb Stroke (Jpn) 44: 19-25, 2016

地方独立行政法人 広島市立病院機構 広島市立広島市民病院 脳神経外科(受稿日 2014.11. 17)(脱稿日 2015. 5. 22)〔連絡先：７ 7308518 広島県広島市中区基町 7-33 地方独立行政法人 広島市立病院機構 広島市立広島市民病院 脳神経外科 村岡賢一郎] [Address correspondence: Kenichiro MuraokA, M.D., Department of Neurosurgery, Hiroshima City Hospital, 7-33 Motomachi, Naka-ku, Hiroshima, Hiroshima 730-8518, Japan] 


\section{緒言}

海綿静脈洞部内頝動脈瘤 (cavernous carotid aneurysm : CCA）は，頭蓋内動脈瘤のうち $2-12 \%$ と報告されている $か^{18222)}$ ，近年の非侵襲的頭蓋内画像検査の一般化により， 無症候性を含めて発見の機会が増加している。一般的に CCA は, carotid caveより遠位の硬膜内脳動脈瘤と比較 して大型化してから症候化する場合が多く，動脈瘤の mass effectによる脳神経症状を呈する場合が多い. 巨大 CCA を除き出血率は低く, 出血発症した場合も, くも膜 下出血はまれで, 多くは頚動脈海綿静脈洞瘦 (carotid artery-cavernous sinus fistula : CCF)を発症する ${ }^{910)}$. つま $り$ ，硬膜内脳動脈瘤と比較して，致死的な，または重篤な 神経症状を後遺する事態にいたる確率は低い。 その特性か ら，症候性病変に関しては積極的治療が勧められるが，無 症候例は基本的に経過観察でよいと考えられている ${ }^{6}$.

CCA に対する治療は，症候化例の多くが動脈瘤の mass effectによる脳神経症状であるため, 動脈瘤の内圧を減 じ，縮小を企図した内䅡動脈閉塞術 (parent artery occlusion：PAO)が基本となる，PAO 施行前には，あらかじめ 内頚動脈バルーン閉塞テスト (balloon test occlusion : BTO) およびSPECTによる脳血流予備能評価を行い, 結 果に応じて適宜 low flow bypass(LFB), high flow bypass (HFB) を併用する ${ }^{7)}$ 。一方，血管内手術に関しては，これ まで PAO の際の internal trap と出血発症例に対する瘤内 コイル塞栓術 (endosaccular coil embolization： ESC)が施
行されてきた ${ }^{919)}$. しかし，近年，周術期管理が進歩し， より安全に施行可能となってきたことに加え, 頭蓋内血管 用ステントが使用可能となり, 多様な CCA 病変に対し て, 内頚動脈 (internal carotid artery：ICA)の順行性血流 を残した ESC が計画的に可能となった ${ }^{315) 8)}$.

今回われわれは, 自験例 10 例において, PAO 4 例, ESC 6 例を施行した. その治療法, 効果, 治療後の経過を まとめ, 文献的報告を交えて, CCA に対する今後の治療 方針に関して考察したので報告する.

\section{対象と方法}

2008 年 1 月から 2014 年 10 月まで，当院にて外科的治 療を行った 10 例 (女性 8 例, 男性 2 例, Table 1). 平均年 齢は 58 歳 (45-70 歳). 動脈瘤の形態・サイズに関しては, saccular type が 8 例で瘤最大径の平均が $14.8 \mathrm{~mm}\left(4.5^{-}\right.$ $21 \mathrm{~mm}$ ), fusiform type は 2 例で病変最長径平均 $33.5 \mathrm{~mm}$ (17-50 mm)であった。脳神経症状にて発症したものが 6 例 (動眼神経麻痺 2 例, 外転神経麻疩 3 例, 両方の合併 1 例), 経過観察中に動脈瘤が増大したものが 2 例, incidental に発見され無症候であったものが 2 例であった．治療 方針の策定においては，まずは $\mathrm{PAO}$ を企図し，脳血管撮 影による側副血行の評価, さらにBTO を施行し, 無症状 であった場合には引き続き $\operatorname{SPECT}\left({ }^{99 \mathrm{~m}} \mathrm{Tc}-\mathrm{ECD}\right)$ を行っ た。これらの結果に従い, (1) PAO 単独, (2) $\mathrm{PAO}+\mathrm{HFB}$ (superficial temporal artery-middle cerebral artery 〔STA$\mathrm{MCA}$ 】吻合による assist bypass 併用), (3) PAO + LFB,

Table 1 Summary of patients with CCA

\begin{tabular}{|c|c|c|c|c|c|c|c|c|c|c|}
\hline Case & $\begin{array}{l}\text { Age/ } \\
\text { gender }\end{array}$ & Side & Symptom & Type & $\begin{array}{l}\text { Maximum } \\
\text { diameter }\end{array}$ & $\begin{array}{l}\text { Lesion } \\
\text { length }\end{array}$ & $\begin{array}{l}\text { Management } \\
\text { of AN }\end{array}$ & $\mathrm{mRS}$ & $\begin{array}{l}\text { Postoperative } \\
\text { symptoms }\end{array}$ & $\begin{array}{l}\text { Complication/ } \\
\text { retreatment }\end{array}$ \\
\hline 1 & $70 / F$ & L & III & Saccular & 13.2 & & $\mathrm{PAO}+\mathrm{HFB}$ & 1 & $\begin{array}{l}\text { Complete } \\
\text { recovery }\end{array}$ & $\begin{array}{l}\text { Chronic stage } \\
\text { cerebral infarction }\end{array}$ \\
\hline 2 & $58 / F$ & L & III & Fusiform & & 17 & $\mathrm{PAO}+\mathrm{HFB}$ & 1 & $\begin{array}{l}\text { Complete } \\
\text { recovery }\end{array}$ & $\begin{array}{l}\text { Perioperative } \\
\text { cerebral infarction }\end{array}$ \\
\hline 3 & $53 / \mathrm{M}$ & L & III, IV & Fusiform & & 50 & PAO + LFB & 1 & Improve & $(-)$ \\
\hline 4 & $57 / F$ & $\mathrm{R}$ & VI & Saccular & 21 & & PAO + LFB & 0 & $\begin{array}{l}\text { Complete } \\
\text { recovery }\end{array}$ & $(-)$ \\
\hline 5 & $58 / F$ & L & VI & Saccular & 12 & & ESC & 2 & No change & Re-embolization \\
\hline 6 & $45 / F$ & $\mathrm{R}$ & Growth & Saccular & 4.5 & & ESC & 0 & $(-)$ & $(-)$ \\
\hline 7 & $70 / F$ & $\mathrm{R}$ & Growth & Saccular & 12.9 & & ESC & 1 & Worse & Abducence palsy \\
\hline 8 & $67 / F$ & L & $(-)$ & Saccular & 21 & & $\begin{array}{l}\text { Stent assist } \\
\text { ESC }\end{array}$ & 0 & $(-)$ & $(-)$ \\
\hline 9 & $49 / \mathrm{M}$ & L & $(-)$ & Saccular & 17 & & $\begin{array}{l}\text { Stent assist } \\
\text { ESC }\end{array}$ & 0 & Worse & $\begin{array}{l}\text { Trigeminal } \\
\text { neuralgia }\end{array}$ \\
\hline 10 & $51 / F$ & L & $\mathrm{VI}$ & Saccular & 17 & & $\begin{array}{l}\text { Stent assist } \\
\text { ESC }\end{array}$ & 1 & No change & $(-)$ \\
\hline
\end{tabular}

CCA: cavernous sinus carotid artery aneurysm, mRS: modified Rankin Scale, M: male, F: female, III: occulomotor nerve, IV: trochlear nerve, VI: abducens nerve, PAO: parent artery occlusion, HFB: high flow bypass, LFB: low flow bypass, ESC: endosaccular coil embolization 

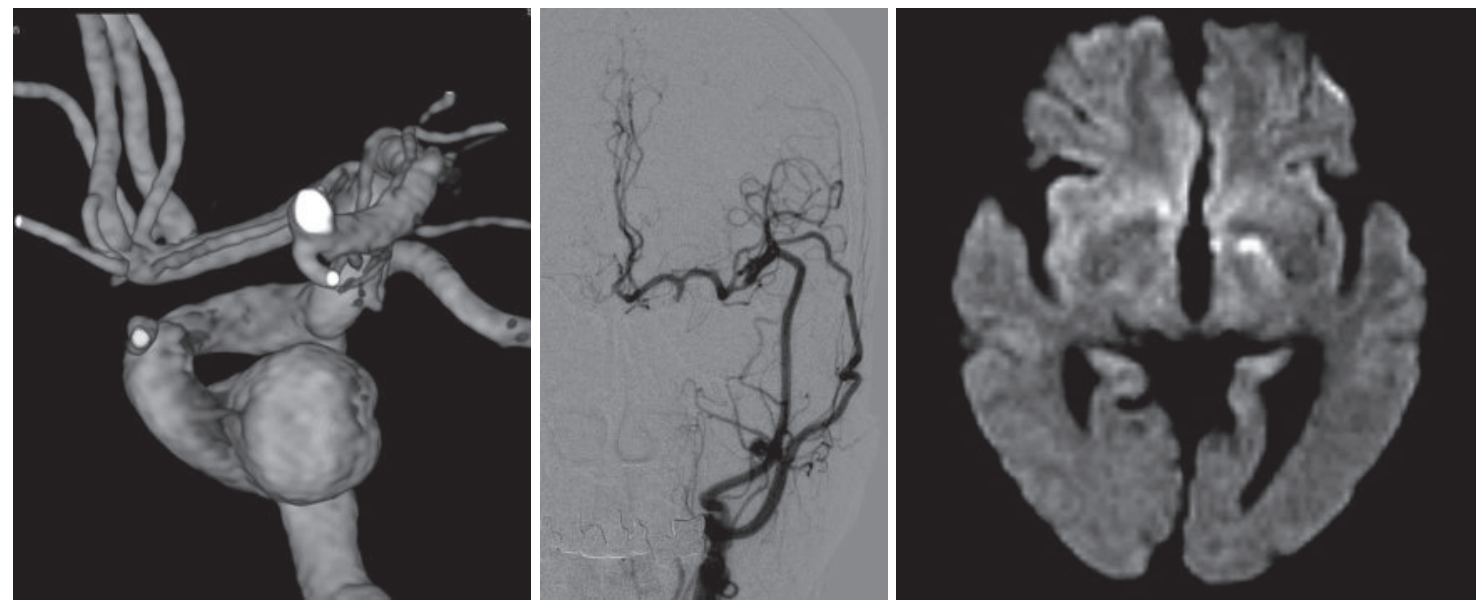

Fig. 1 A: Left internal carotid angiography (ICAG) 3-dimensional rotational angiography(3-

A $|\mathbf{B}| \mathbf{C}$ D RA) (LAO40) revealing a large cavernous carotid aneurysm (CCA). B: Left ICAG: at 3.5 months after operation confirming the patency of both the radial artery (RA) and superficial temporal artery (STA) grafts.

C: Diffusion weighted imaging (DWI) magnetic resonance (MR) image of an ischemic event at 3.5 months after operation, revealing a hyper-signal in the left internal capsule.

(4)瘤内塞栓術 (ESC), (5)ステント併用 ESC の 5 つから選 択した。基本戦略として PAO 群と ESC 群に分けて, 2 群 の特徵を比較した. HFB 施行時のグラフトは radial artery $(\mathrm{RA})$ を用いた。 あらかじめ ESC 単独での治療を企図 した 2 例に関しては BTO を施行しなかった.

\section{結果}

治療の基本戦略は PAO 群 4 例と $\mathrm{ESC}$ 群 6 例であった. $\mathrm{PAO}$ 群の内訳は HFB 併用 2 例, LFB 併用 2 例であっ た.PAO 群は全例脳神経症状により発症した症候性であ り, 術後に 3 例は症状が消失, 1 例は改善した。 しかし, HFB 併用 2 例において虚血性合併症を認め, いずれも術 後 6 力月の時点で mRS 1 であった. LFB 併用群は合併症 を認めなかった. ESC 群では, 塞栓術単独 3 例, ステン 卜併用塞栓術 3 例であった。 症候性の 2 例は, 術後も症状 不変であった，術前に無症候性であった 4 例においては, 術後に外転神経不全麻瘦が 1 例, 三叉神経痛 (V1 領域) が 1 例に出現したＥSC 群で周術期および遠隔期に虚血性・ 塞栓性合併症はなかった。 また, ESC 群の 1 例に再治療 (追加塞栓)を要した.

\section{症例}

〈症例 1〉70 歳, 女性.

主訴：複視

現病歴：左動眼神経麻痺にて発症．頭部精査にて左海綿 静脈洞部動脈瘤の診断.
検査所見：脳血管撮影検查にて動脈瘤サイズは $11.3 \times$ $10.8 \times 13.2 \mathrm{~mm}($ Fig. 1A) . 前交通動脈, 後交通動脈を介し た側副血行がそしかったため BTO は施行しなかった.

治療経過：手術では RA-M2 吻合時の MCA 一時遮断の 虚血対策として assist bypass (左 STA-MCA 吻合術) 施 行. 次に HFB を施行し, 引き続き頝部にて ICAを結紮し た. 術直後, 軽度呂律困難, 錯語症状を認めたが一過性で あった.アスピリンの内服を開始し, 術後 25 日目, 自宅 退院した.

術後 3.5 力月経過時点で右不全片麻疩を発現し, 当院へ 救急搬送された，DSAにてRA graft, STA graftはいず れも開存していたが(Fig. 1B)，MRIでは左内包に新鮮梗 塞を認めた (Fig. 1C). 入院し脳梗塞に準じて 2 週間の投 薬治療,リハビリテーション施行. ADLはほぼ自立した ため自宅退院した.

治療結果：modified Rankin Scale (mRS) 1

〈症例 4〉 57 歳, 女性.

主訴：右方視の複視

現病歴：複視と立ちくらみを自覚し当科受診.診察時,

右外転神経麻痺を認め, 頭部 MRIにて右内䅡動脈瘤を認 めた(Fig. 2A).

検查所見：DSA にて右海綿静脈洞部に $21 \times 17 \mathrm{~mm}$ の動 脈瘤(Fig. 2B). BTO・SPECT にて虚血耐性あり。

治療経過：先行して LFB 術を施行し，7 日後に internal trap を施行 (Fig. 2C). 術後に外転神経麻疩は軽快. 1 年後 

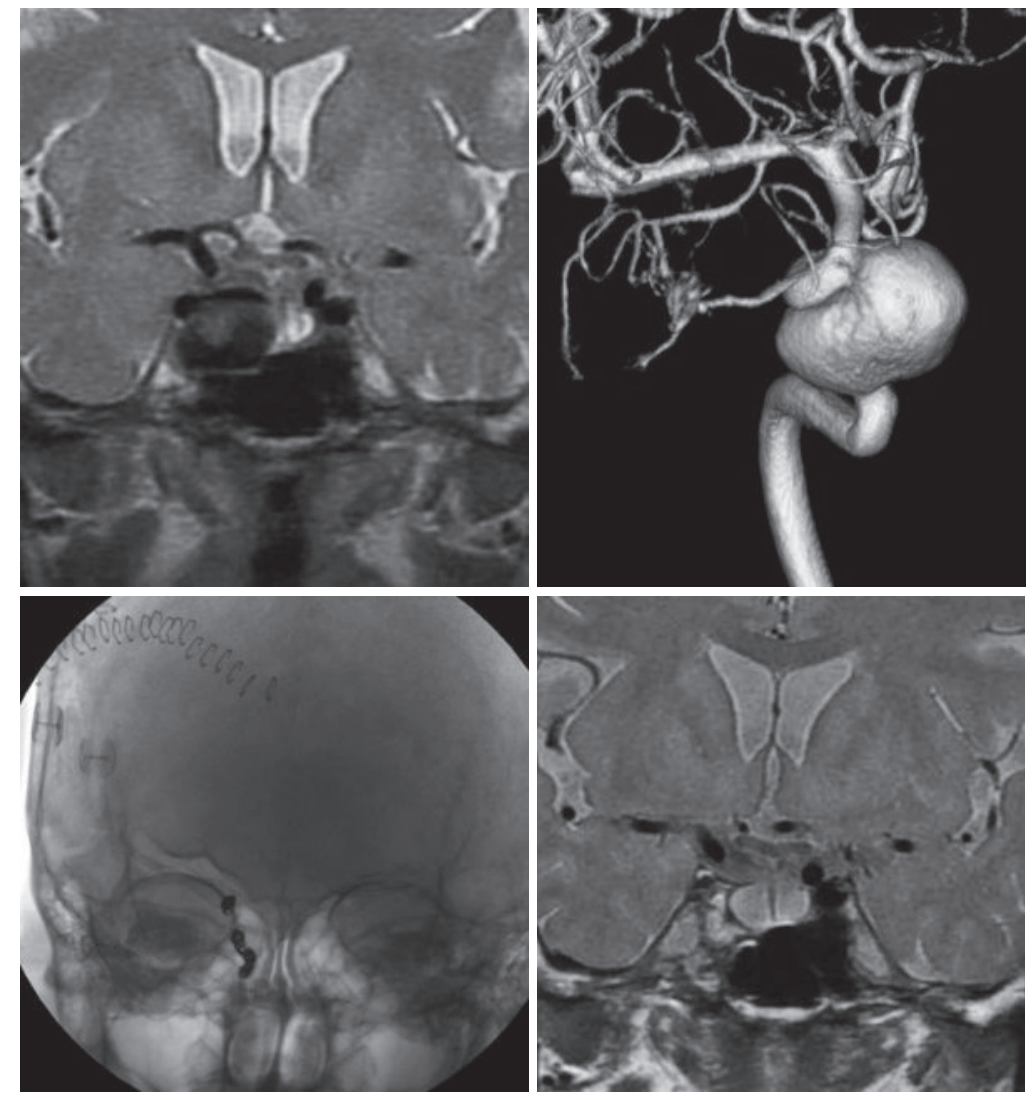

\section{A $B$ \\ C $\mathbf{D}$}

Fig. 2 A: Pretreatment coronal view T2-weighted imaging (T2WI) MRI demonstrating the flow-void CCA in the right side of the sella turcica.

B: Right ICAG 3-D RA revealing a large CCA.

C: Posttreatment radiograph demonstrating two coil masses used as internal traps at the distal and proximal sites of the aneurysm neck.

D: Posttreatment coronal view T2WI MRI revealing shrinking of the CCA.
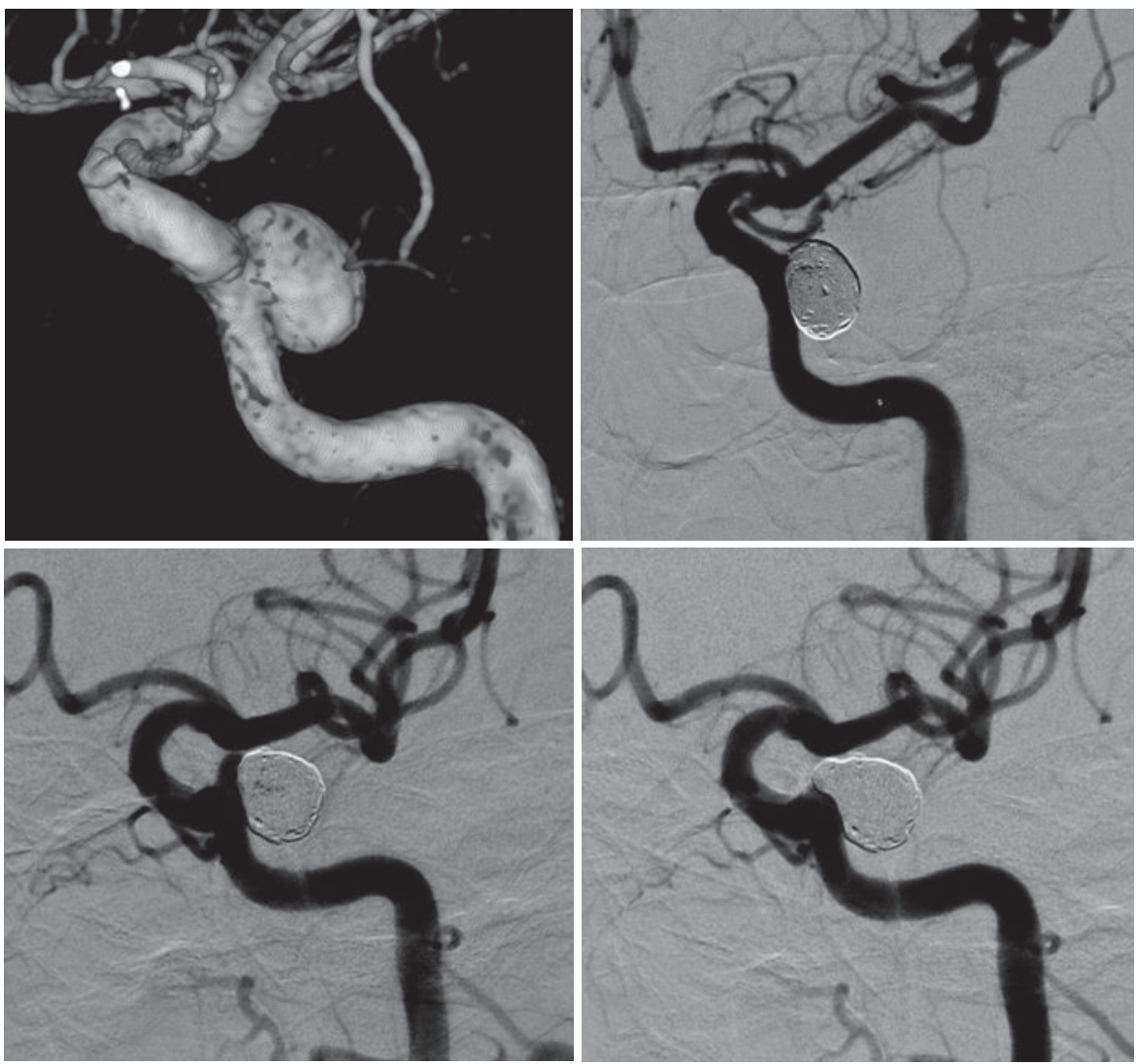

\section{A $\mid$ B}

Fig. 3 A: Left ICAG 3-D RA revealing large CCA.

B: Post-first embolization left ICAG. Although a small residual space is seen in the inflow zone, almost complete embolization was achieved (Raymond class 2).

C: At 2 years after the first coil embolization, the left ICAG shows a regrowth in the inflow zone.

D: Post-second embolization left ICAG: The site of the recurrence is embolized tightly. 

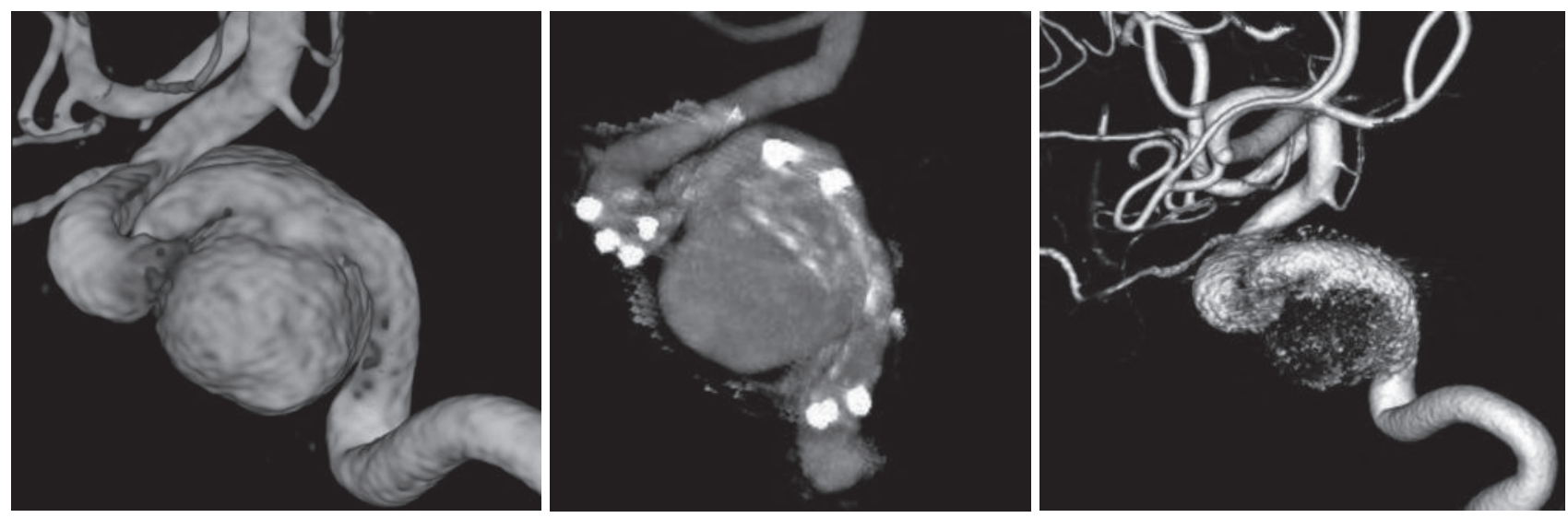

Fig. 4 A: Pretreatment left ICAG 3-D RA revealing a large CCA.

$\mathbf{A}|\mathbf{B}| \mathbf{C}$

B: Post-stent deployment cone-beam computed tomography (CT) image showing the stent and 2 tip markers of the microcatheters at the midportion of the stent.

C: Post-embolization left ICAG 3-D RA demonstrating ICA patency.

の MRIにて動脈瘤の縮小が確認された(Fig. 2D). 治療結果：mRS 0

〈症例 5〉58 歳, 女性.

主訴：複視

現病歴：左外転神経麻痺にて発症. 頭部精査にて左海綿 静脈洞部内澒動脈瘤の診断.

検査所見：脳血管撮影検査にて動脈瘤サイズは $10 \times 12$ $\times 8.2 \mathrm{~mm}($ Fig. 3A). BTO にて神経症状を認めたため, 虚 血耐性がないと判断.

治療経過：動脈瘤の形状から瘤内塞栓可能であったた め, 母動脈の patency 維持を企図し, 瘤内コイル塞栓術 を施行した(Fig. 3B). 手術は予定通り施行し得たが, 術 後に神経症状は改善しなかった. 治療から 2 年後, inflowzone に再発を認めたため(Fig. 3C), 追加塞栓施行 (Fig. 3D). 再治療後 3 年経過時点で, 動脈瘤は消失している が, 神経症状は初回治療前から変化を認めない.

〈症例 8〉67 歳, 女性.

主訴：頭痛

現病歴 : 頭痛の精查に近医で頭部 MRIを施行し異常を 指摘され，当院を紹介受診.

画像所見：脳血管撮影検査にて左海綿静脈洞部動脈瘤 (長径 $21 \times 18 \mathrm{~mm}$, neck $9.5 \mathrm{~mm})$ (Fig. 4A).

治療経過：右大腿動脈からアプローチし, 左内澒動脈に 頭蓋内ステント (Neuroform $4.5 \times 30 \mathrm{~mm}$ )を展開し(Fig. 4B), 瘤内塞栓施行. Penumbra PC400 シリーズを中心に 合計 14 本のコイルで塞栓完了(Fig. 4C). 術前計画通り内 頚動脈の開存を確保し, 手術を終了した。術後, 神経症状
は出現せず自宅退院.

治療結果：mRS 0

考察

われわれが経験したCCA 10 症例は,この部位の動脈瘤 特有の病態不均一性により，治療法や術後経過もさまざま であった。その中には，PAOを主体とする治療と ICAの patency を企図する ESC, それぞれの治療法特有の利点・ 欠点が集約されていた.PAOにおいては症候性 CCAに 対する PAO 4 例中, 神経症状の消失が $75 \%$ (3 例), 改善 が $25 \%$ (1 例)であり, 全例に治療効果が得られたが, $\mathrm{PAO}+\mathrm{HFB}$ の 2 例で虚血性合併症を認めた。つまり，脳 神経症状に対する治療効果の確実性という利点と周術期か ら遠隔期にかけて虚血性合併症の危険を伴うという久点で ある。一方， $\operatorname{ESC} 6$ 例においては，周術期虚血性合併症を 発生しなかったが, 症状の変化に関しては, 症候性 2 例は いずれも no change, 無症候性 4 例中 2 例は術後に脳神経 症状が出現した。症状改善率という点では $0 \%$, 無症候例 において $50 \%$ で症候化した，再治療率は $16.7 \%$ であっ た. ESCにおいては, 比較的計画通りに周術期を乗り切 ることが見込まれる治療自体の確実性・安全性という利点 と mass effectの残存による神経症状の遷延や再治療の可 能性があるという欠点がある.

CCAの多くが mass effectにより発症するため, 症状改 善のために動脈瘤の内圧を減じ, さらには動脈瘤体積縮小 を企図したPAOが標準的治療として選択される。そし て, PAOによる脳血流変化に備えた術前の脳血流予備能 評価法も, 多くの経験の蓄積により確立されつつあり, LFB， HFB 併用の判断基準となっている ${ }^{4) 7}$. しかし，比 
較的合併症率が低い手技である $\mathrm{PAO}$ 単独においても, 脳 血流予備能評価における false negative が存在することに 留意しなくてはならない ${ }^{12)}$ 。また，バイパス手術を併用す る場合には外科的手技に伴う普遍的リスクが加わるこ と, さらに血行動態変化による予測困難な周術期および遠 隔期の虚血性合併症の可能性があることにも留意する必要 がある ${ }^{113)}$. そして, 脳神経症状改善目的に, 内颈動脈を 閉塞させるという術式に対する，術者の心理的抵抗感も否 定できない.

近年，急速に発達，導入されつつある ESCに関して は，標準治療として施行されている PAOに対し，内頚動 脈の生理的順行性血流を確保しながら動脈瘤に対して治療 できるという利点とともに，直接の手術侵襲が基本的に鼠 径部穿刺のみであるため, 周術期から遠隔期にいたるまで 合併症軽減効果が得られる可能性がある ${ }^{5)}$. また, 患者の 身体的・精神的負担も軽減する。 しかし, 治療法の限界と して, 動脈瘤自体は mass として残存するため, 瘤内への 血流が消失することで water hummer effect は消失するも のの, 本来の治療目的である神経症状の軽減という点にお いては, PAO と比較して改善率が低いと報告されてい $ろ^{11)}$.

2 つの治療法の成績に関して諸家の報告を参考にする と, Van Rooij $ら^{20)}$ は, 脳神経症状にて発症した症候性病 変に対し BTO を施行し，陰性ならばPAOを，陽性の場 合には全例 ESC を選択し, 治療成績を比較している。彼 らによると, PAO と ESCにおいて, 治療効果に統計学的 差は認められず，同時にいずれの治療法においても合併症 も認めなかった ${ }^{20)}$. Starke $ら^{14)}$ も同様の成績を報告してい る。われわれはPAOにより良好な症状改善効果を得た が，ESCでは神経症状改善が得られなかった。この原因 の 1 つして, 塞栓術戦略が異なることが考えられた。一 般的に ESC においては, 体積塞栓率 (volume embolization ratio：VER）を上げ，動脈瘤の描出を消失させることを目 指すが，彼らはVERにこだわらず，むしろ瘤内塞栓は loose packing に抑えており，さらにステントを多用して いる ${ }^{20)}$. VER の低下は ESC の課題である再治療率の高さ を助長すると予想されるが, 彼らは良好な神経症状改善率 と再発率上昇抑制を両立させている。VERやコイル選択 に関する詳細な戦略に関しては，情報が不十分である が, 少なくともわれわれの現行の塞栓術戦略では, PAO に相当する症状改善効果は得られておらず改善が必要であ

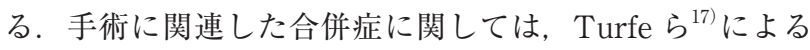
メタアナリシスによれば, PAO と ESC 間に術後合併症 率, 死亡率について有意差が認められず差異については不 明であったとされている。自験例では HFB 併用手術にお いて高率に虚血性合併症を続発した。 HFB は，施行頻度
が増したことで, 特殊手術ではなくなりつつある手技では あるが, 煩雑でピットフォールの多い手技であり, われわ れとしては, 適切な治療結果を得るために, 特に虚血性合 併症低減のための手技の確害性・安全性向上が喫緊の課題 である．現時点で症候性病変に対する根治療法は PAO が 基本であり，諸家の報告を参考にすると poor riskで $\mathrm{BTO}$ 陽性例において, 症状の進行予防を治療目標と設定するよ うな限定的条件下において ESC はPAO の代替治療とな る可能性がある(3) (15).

CCA に対する治療はPAO が主体となるため, これま で無症候性病変は巨大動脈瘤を除き積極的治療適応となら なかったしかし，ESCにより血行動態への影響なく動 脈瘤を消失させるという視覚的に明快な結果が得られるこ と, およびその低侵襲性から, 近年 incidental に発見され る CCA の増加に伴い, 治療適応が無症候性病変へ拡大さ れてきた，無症候性病変に対する治療介入基準として Choulakian $ら^{2)}$ は, 最大径 $17 \mathrm{~mm}$ を症候化の境界として 報告している。われわれのCase 9 は，まさに最大径 $17 \mathrm{~mm}$ の CCA が一過性の外転神経麻疩により発見され, その妥当性を実感した。 しかし, 神経症状の長期予後に関 して Stiebel-Kalish $~^{15)}$ が, ESCでは動脈瘤の mass effect が残存するため, 治療介入後も CCA の自然歴と比較して 有意な症状の改善効果は得られないと結論づけているよう に, ESC の治療効果は不確実である. 症候化の予測因子 としては, サイズ以外に lesion segment, morphology, projection など複数の要素が複雑に交絡すると考えら $れ^{21)}$, 症候化リスクを定量化し, 症候化予防目的の治療適 応を決定することは難しい.

われわれは無症候性 4 例中 2 例に, 術後脳神経症状の出 現を経験した。 これは, 治療戦略において, 硬膜内の分岐 部動脈瘤に対する破裂予防目的の tight packing を基本と した戦略が, side wall type で mass effectにて発症する CCA においては適切でない可能性を示唆している. 前述 したV Van Rooij ら ${ }^{20)}$ の戦略を参考にすると, 病変部の ICA に整流効果をつくり出すことが, 動脈瘤内圧を低下さ せ, 進行予防効果を得ている可能性がある. このメカニズ ムを用いた治療を具現化するため, 現在 flow diverter stentが試されている。これは, 瘤内塞栓を行わず, 整流 効果のみで瘤内圧減少・サイズ縮小を企図したものであ り, 症候の有無にかかわらず有効となり得るデバイスとし て期待される. しかし, 依然, その治療効果, 使用に伴う 危険性など, 不明な点が残っており, さらなる検証が必要 である ${ }^{16)}$ ，つまり，CCAに対する ESC または血管内手術 は, 確実で安定した治療効果を得るために開発途上にある といえる. 現時点では安易な治療適応拡大は時期尚早であ り, 本来の治療目的を見据えた慎重な適応判断が重要と考 
えられた。

\section{結語}

CCA は，その疾患の特性上，脳神経症状にて発症する ことが圧倒的に多く, その場合の治療法としては, 可及的 に安全・確実であることが求められる. その際, 治療法の 違いが術後の神経症状の変化, 合併症・後遺症に影響する ため, 適応, 戦略の判断には慎重でなくてはならない. 近 年, 頭蓋内動脈瘤に対する治療として HFB を含めた血行 再建を併用するPAO が多くの施設で施行されるようにな り, 同時に母動脈温存を可能とする頭盍内ステント含めた 多様な adjunctive technique を駆使した ESC を施行可能 な施設が増え, 単一施設でいずれの治療法も施行すること が可能となってきた，それぞれの治療法の特性を考慮 し, その治療効果を予測し, 病変側の因子, 患者が治療結 果に求めることを加味して, より適切で確実な治療法を選 ぶことが重要と思われる.

著者全員は日本脳神経外科学会への COI 自己申告を完 了しています，本論文の発表に関して開示すべきCOI は ありません。

\section{文献}

1) Chibbaro S, Tacconi L: Extracranial-intracranial bypass for the treatment of cavernous sinus aneurysms. J Clin Neurosci 13: 1001-1005, 2006

2) Choulakian A, Drazin D, Alexander MJ: Endosaccular treatment of 113 cavernous carotid artery aneurysms. J Neurointerv Surg 2: 359-362, 2010

3) Drazin D, Choulakian A, Nuño M, et al: Improvement in visual symptomatology after endovascular treatment of cavernous carotid aneurysms: a multicenter study. J Vasc Interv Neurol 6: 15-21, 2013

4) Field M, Jungreis CA, Chengelis N, et al: Symptomatic cavernous sinus aneurysms: management and outcome after carotid occlusion and selective cerebral revascularization. AJNR Am J Neuroradiol 24: 1200-1207, 2003

5) Goldenberg-Cohen N, Curry C, Miller NR, et al: Long term visual and neurological prognosis in patients with treated and untreated cavernous sinus aneurysms. J Neurol Neurosurg Psychiatry 75: 863-867, 2004

6) Johnston SC, Higashida RT, Barrow DL, et al: Recommendations for the endovascular treatment of intracranial aneurysms: a statement for healthcare professionals from the Committee on Cerebrovascular Imaging of the American Heart Association on Cardiovascular Radiology. Stroke 33: 2536-2544, 2002

7) Kai Y, Hamada J, Morioka M, et al: Treatment strategy for giant aneurysms in the cavernous portion of the internal ca- rotid artery. Surg Neurol 67: 148-155, 2007

8) Koebbe CJ, Veznedaroglu E, Jabbour P, et al: Endovascular management of intracranial aneurysms: current experience and future advances. Neurosurgery 59(5 Suppl 3): S93-102, 2006

9) Kupersmith MJ, Stiebel-Kalish H, Huna-Baron R, et al: Cavernous carotid aneurysms rarely cause subarachnoid hemorrhage or major neurologic morbidity. J Stroke Cerebrovasc Dis 11: 9-14, 2002

10) Linskey ME, Sekhar LN, Hirsch WL Jr, et al: Aneurysms of the intracavernous carotid artery: natural history and indications for treatment. Neurosurgery 26: 933-937, 1990

11) Morita $K$, Sorimachi $T$, Ito $Y$, et al: Intra-aneurysmal coil embolization for large or giant carotid artery aneurysms in the cavernous sinus. Neurol Med Chir (Tokyo) 51: 762-766, 2011

12) Murakami K, Shimizu H, Matsumoto Y, et al: Acute ischemic complications after therapeutic parent artery occlusion with revascularization for complex internal carotid artery aneurysms. Surg Neurol 71: 434-441, 2009

13) Park EK, Ahn JS, Kwon do H, et al: Result of extracranial-intracranial bypass surgery in the treatment of complex intracranial aneurysms : outcomes in 15 cases. $J$ Korean Neurosurg Soc 44: 228-233, 2008

14) Starke RM, Chalouhi N, Ali MS, et al: Endovascular treatment of carotid cavernous aneurysms: complications, outcomes and comparison of interventional strategies. J Clin Neurosci 21: 40-46, 2014

15) Stiebel-Kalish H, Kalish Y, Bar-On RH, et al: Presentation, natural history, and management of carotid cavernous aneurysms. Neurosurgery 57: 850-857, 2005

16) Szikora I, Berentei Z, Kulcsar Z, et al: Treatment of intracranial aneurysms by functional reconstruction of the parent artery: the Budapest experience with the pipeline embolization device. AJNR Am J Neuroradiol 31: 1139-1147, 2010

17) Turfe ZA, Brinjikji W, Murad MH, et al: Endovascular coiling versus parent artery occlusion for treatment of cavernous carotid aneurysms: a meta-analysis. J Neurointerv Surg 7: 250-255, 2015

18) Unruptured intracranial aneurysms - risk of rupture and risks of surgical intervention. International Study of Unruptured Intracranial Aneuryms Investigotors. $N$ Engl J Med 339: 1725-1733, 1998

19) van der Schaaf IC, Brilstra EH, Buskens E, et al: Endovascular treatment of aneurysms in the cavernous sinus: a systematic review on balloon occlusion of the parent vessel and embolization with coils. Stroke 33: 313-318, 2002

20) van Rooij WJ, Sluzewski M: Unruptured large and giant carotid artery aneurysms presenting with cranial nerve palsy: comparison of clinical recovery after selective aneurysm coiling and therapeutic carotid artery occlusion. AJNR Am J Neuroradiol 29: 997-1002, 2008

21) van Rooij WJ: Endovascular treatment of cavernous sinus aneurysms. AJNR Am J Neuroradiol 33: 323-326, 2012

22) Vasconcellos LP, Flores JA, Veiga JC, et al: Presentation and treatment of carotid cavernous aneurysms. Arq Neuropsiquiatr 66: 189-193, 2008 